\title{
Byssochlamys spectabilis
}

National Cancer Institute

\section{Source}

National Cancer Institute. Byssochlamys spectabilis. NCI Thesaurus. Code C127694.

A species of fungi in the family Trichocomacae characterized by broadly ellipsoidal to lemon-shaped conidia, loosely branched conidiophores and phialides with pointed tips. B. spectabilis is strongly heat-resistant and is a common contaminant of heat-treated foods and juices. 